\title{
UDC 657
}

\section{PROBLEMS OF FORMATION OF CONSOLIDATED FINANCIAL STATEMENTS IN UKRAINE AND WAYS OF ITS SOLUTION}

Bohdaniuk O.V.

PhD, as. prof./ к.е.н., доиент

ORCID: 0000-0002-8354-9933

Lebedko A.V.

Student / студентка

National University of Life and Environmental Sciences of Ukraine,

Heroiv Oborony, 15, 03041

Національний університет біоресурсів і природокористування України, м. Київ, Героїв Оборони, 15, 03041

\begin{abstract}
The need to submit consolidated financial statements in Ukraine is caused by the emergence of holding companies, concerns, other groups, as well as joint stock companies with a significant number of subsidiaries. However, despite the fact that a long time has passed since the introduction of Standard 2 in the practice of accounting for domestic companies, there are some problematic issues that we try to cover in this article.
\end{abstract}

Key words: consolidated financial statements, Accounting Regulations, reporting, Ukraine

\section{Introduction.}

The need to submit consolidated financial statements in Ukraine is caused by the emergence of holding companies, concerns, other groups, as well as joint stock companies with a significant number of subsidiaries. However, the presentation of consolidated financial statements became real only with the adoption of National Accounting Regulations (Standards), in particular Standard 2 «Consolidated financial statements» [3]. Until now, groups of enterprises, interconnected by the system of participation, have compiled consolidated financial statements according to the traditional method using elements of consolidation. However, despite the fact that a long time has passed since the introduction of Standard 2 in the practice of accounting for domestic companies, there are some problematic issues that we try to cover in this article.

\section{Main text.}

The method of preparation of the consolidated financial statements is quite complex, as it is necessary to eliminate the elements, i.e. the consequences of agreements between group members are not included in the consolidated financial statements, only assets and liabilities, income and expenses of third parties are reflected. Therefore, in order to obtain reliable information about the group's activities, it is necessary to implement uniform accounting and control procedures for consolidation purposes at the group level [1].

Today, there are different approaches to the formation of consolidated financial statements: on the basis of individual financial statements of companies or through a consolidated accounting system.

The development of a consolidated accounting system is to define a consolidated group of companies as an object of accounting and to develop a consolidated accounting system that provides the necessary information at all levels 
of management of the holding company and serves as a basis for consolidated financial statements.

Increased competition in the domestic market and intensification of economic struggle in the international market is an important prerequisite for centralization and pooling of capital of economic entities, which, given the specifics of their relationships and activities, consolidated financial statements.

Strengthening competition in the domestic market and intensifying the economic struggle in the international (foreign) market is an important prerequisite for the centralization and pooling of capital of economic entities, which, given the specifics of their relationships and activities, consolidated financial statements.

A particular problem faced by multinational corporations in preparing consolidated financial statements is that their components - the financial statements of organizational units - are denominated in different currencies. To compile a consolidated balance sheet of a company consisting of the parent company of one country and subsidiaries of another, it is necessary that the elements of both balance sheets be denominated in one currency, usually in the currency of the parent company. The transfer process is associated with some problems that arise due to the fact that exchange rates are not fixed, i.e. the question arises as to how much exchange rate should be used when transferring from one currency to another, if at the time the purchase rate was different from the current rate. In practice, assets and liabilities are converted using the opening or closing rate. However, in world practice there are no general principles according to which a clearly defined type of exchange rate would be used to transfer the value of certain types of assets. Therefore, this issue remains unresolved.

Consolidation is practically undeveloped in Ukraine. This is due to a number of reasons, the main of which is the low role of commercial users of accounting information in the process of determining the principles and standards of accounting and reporting, as well as the fact that the main role in this process is played by government agencies. We can identify the main issues of consolidated reporting in Ukraine (Table 1).

Table 1

Problems of preparation of consolidated financial statements

\begin{tabular}{|l|l|}
\hline \multicolumn{1}{|c|}{ Organizational problems } & \multicolumn{1}{c|}{ Problems of methodical character } \\
\hline The complexity of regulatory regulation & $\begin{array}{l}\text { The complexity of collecting and structuring } \\
\text { accounting data in order to compare them }\end{array}$ \\
\hline $\begin{array}{l}\text { The complexity of the process of organizing } \\
\text { accounting for the needs of consolidated } \\
\text { financial statements }\end{array}$ & Multicurrency \\
\hline $\begin{array}{l}\text { The use of different software products and the } \\
\text { complexity of their implementation }\end{array}$ & $\begin{array}{l}\text { Impossibility to determine the contribution of an } \\
\text { individual company to the indicators of the } \\
\text { group }\end{array}$ \\
\hline Insufficient number of specialists & $\begin{array}{l}\text { The difficulty of determining the amount } \\
\text { of unrealized gains and shares in equity }\end{array}$ \\
\cline { 2 - 3 } & $\begin{array}{l}\text { High complexity and duration of reporting and / } \\
\text { or its transformation }\end{array}$ \\
\cline { 2 - 2 } & $\begin{array}{l}\text { Lack of methods for analyzing consolidated } \\
\text { financial statements }\end{array}$ \\
\hline
\end{tabular}


For external users, the consolidated financial statements provide additional information that eliminates the limitations of separate financial statements. Therefore, when developing the organization and methodology of preparation of consolidated financial statements, it is necessary to take into account all the characteristics of consolidated financial statements. In general, the organization of preparation of consolidated financial statements determines the methodology of preparation of consolidated financial statements, the technology of preparation of consolidated financial statements and reporting entities (Table 2).

Table 2

Recommendations for the preparation of consolidated financial statements in accordance with IFRS 10 and National Standard 2

\section{IFRS 10 \\ Consolidated Financial Statements [2]}

Consolidated financial statements:

(i) similar items of assets, liabilities, equity, income, expenses and cash flows of the parent are combined with similar items of its subsidiaries;

(ii) the carrying amount of the parent's investments in each subsidiary and the parent's interest in the equity of each subsidiary is reduced (IFRS

3 "Business combination" explains the procedure for accounting for any relevant goodwill);

(iii) intragroup assets and liabilities, capital, income, expenses and cash flows related to transactions between group entities are completely excluded

Unified accounting policy. If an accounting policy other than the general one is used, appropriate adjustments should be made to ensure consistency with the group's accounting policies

An entity shall include the income and expenses of the subsidiary in the consolidated financial statements from the date on which it has acquired control of the subsidiary until the date on which the entity loses control of the subsidiary.

The financial statements of the parent and its subsidiaries used in the preparation of the consolidated financial statements must have the same reporting date

\section{National Standard 2} "Consolidated Financial Statements" [3]

The financial statements of the parent and its subsidiaries are the same

reporting period and on the same balance sheet date

Consolidated financial statements consist of the financial statements of a group of entities using a single accounting policy for similar transactions and other events under similar circumstances. If it is not possible to apply a single accounting policy, this is reported in the notes

Consolidated financial statements are prepared by orderly adding financial statements of subsidiaries to similar financial statements parent company.

When preparing consolidated financial statements are subject to exclusion:

(i) the carrying amount of the parent's financial investments in each subsidiary and the parent's interest in the equity of each subsidiary;

(ii) the amount of intragroup transactions and intragroup balance;

(iii) the amount of transactions and intragroup balance;

(iv) the amount of unrealized gains and losses from intragroup transactions (except for losses that cannot be reimbursed).

For the preparation of consolidated financial statements, the parent determines the uncontrolled share in equity, net profit (loss) and total income of subsidiaries. 
Thus, the consolidation process involves the implementation of certain consolidation procedures, ie a certain sequence of accounting actions for the formation of financial statements, in turn, the consolidation procedure is defined as part of the consolidation process and is a set of accounting operations and actions of methodological and organizational nature and interdependence.

Consolidated financial statements are calculated and formed on the basis of individual financial statements of companies, so it is impractical to talk about the existence and application of consolidated financial statements. Consolidated financial statements, which are based on all indicators of controlled companies, should reflect the real estate and financial condition of all companies, as well as belong to the scope of consolidation as a single economic unit, as well as a comparative analysis of all methods of consolidated financial statements.

\section{Conclusions.}

We share the view of scholars that multinational companies whose participation should be transferred for the preparation of consolidated financial statements in accordance with IFRS, because:

1. their reports must be confirmed by the audit firm and published in the media;

2. these companies serve not only the Ukrainian market, but also other countries, so their reports should be unified and understandable to all interested users;

3. the interest of foreign investors in the work and with the companies of Ukraine requires the preparation of financial statements in accordance with IFRS for its understanding, analysis and management decisions.

The benefits of preparing financial statements in accordance with international standards exist and are obvious to most users of financial statements. IFRS can be seen as a tool for globalization of the economy and global economic relations. The principles set out in the IFRS reporting order make it more adequate and able to reflect the organization's real assets. Therefore, the value of IFRS is important not only for foreign investors but also for domestic investors. This once again confirms the need and usefulness of the IFRS implementation process for all sectors of the Ukrainian economy.

\section{References.}

1. Міжнародний стандарт бухгалтерського обліку 27 «Консолідована та окрема фінансова звітність» URL: http://zakon2.rada.gov.ua/laws/show/929 045

2. Міжнародний стандарт фінансової звітності 10 «Консолідована фінансова звітність» Редакція від 01.01.2013. URL: https://zakon.rada.gov.ua/laws/show/929 065

3. Національне положення (стандарт) бухгалтерського обліку 2: Наказ Міністерства фінансів України від 27.06.2013 р. № 628. URL: http://zakon2.rada.gov.ua/laws/show/z1223-13

4. Національне положення (стандарту) бухгалтерського обліку 1 «Загальні вимоги до фінансової звітності»: Наказ Міністерства фінансів України від 28.02.2013 p. № 336/22868. URL: https://zakon.rada.gov.ua/laws/show/z0336-13 
Анотація. Необхідність подання консолідованої фінансової звітності в Україні викликана появою холдингових компаній, концернів, інших груп, а також акціонерних товариств зі значною кількістю дочірніх компаній. Однак, незважаючи на те, щзо з часу впровадження Наџіонального Стандарту 2 «Консолідована фінансова звітність» на практииі бухгалтерського обліку вітчизняних компаній минуло досить багато часу, $\epsilon$ декілька проблемних питань, які ми намагаємось висвітлити у даній статті.

Ключові слова: консолідована фінансова звітність, Положення про бухгалтерський облік, звітність, Україна

Стаття направлена: 16.05.2021 p. (C) Богданюк О.В., Лебедько А.В. 